Article

\title{
An In Vitro Study on the Antimicrobial Properties of Essential Oil Modified Resin Composite against Oral Pathogens
}

\author{
Barbara Lapinska ${ }^{1}$ (D), Aleksandra Szram ${ }^{1}$, Beata Zarzycka ${ }^{2}$, Janina Grzegorczyk ${ }^{2}$, \\ Louis Hardan ${ }^{3}$, Jerzy Sokolowski ${ }^{1}$ and Monika Lukomska-Szymanska ${ }^{1, *(D)}$ \\ 1 Department of General Dentistry, Medical University of Lodz, 92-213 Lodz, Poland; \\ barbara.lapinska@umed.lodz.pl (B.L.); ola.wilzak@gmail.com (A.S.); jerzy.sokolowski@umed.lodz.pl (J.S.) \\ 2 Department of Microbiology and Laboratory Medical Immunology, Medical University of Lodz, \\ 92-213 Lodz, Poland; beata.zarzycka@umed.lodz.pl (B.Z.); janina.grzegorczyk@umed.lodz.pl (J.G.) \\ 3 Department of Restorative Dentistry, Dental School, Saint Joseph University, 11072180 Beirut, Lebanon; \\ louis.hardan@usj.edu.lb \\ * Correspondence: monika.lukomska-szymanska@umed.lodz.pl; Tel.: +85-42-675-74-61
}

Received: 17 August 2020; Accepted: 28 September 2020; Published: 1 October 2020

\begin{abstract}
Modifying the composition of dental restorative materials with antimicrobial agents might induce their antibacterial potential against cariogenic bacteria, e.g., S. mutans and L. acidophilus, as well as antifungal effect on C. albicans that are major oral pathogens. Essential oils (EOs) are widely known for antimicrobial activity and are successfully used in dental industry. The study aimed at evaluating antibacterial and antifungal activity of EOs and composite resin material (CR) modified with EO against oral pathogens. Ten EOs (i.e., anise, cinnamon, citronella, clove, geranium, lavender, limette, mint, rosemary thyme) were tested using agar diffusion method. Cinnamon and thyme EOs showed significantly highest antibacterial activity against $S$. mutans and L. acidophilus among all tested EOs. Anise and limette EOs showed no antibacterial activity against $S$. mutans. All tested EOs exhibited antifungal activity against $C$. albicans, whereas cinnamon EO showed significantly highest and limette EO significantly lowest activity. Next, 1,2 or $5 \mu \mathrm{L}$ of cinnamon EO was introduced into $2 \mathrm{~g}$ of CR and microbiologically tested. The modified CR showed higher antimicrobial activity in comparison to unmodified one. $\mathrm{CR}$ containing $2 \mu \mathrm{L}$ of EO showed the best antimicrobial properties against $S$. mutans and C. albicans, while CR modified with $1 \mu \mathrm{L}$ of EO showed the best antimicrobial properties against L. acidophilus.
\end{abstract}

Keywords: essential oils; oral pathogens; antibacterial activity; S. mutans; L. acidophilus; C. albicans; antifungal activity

\section{Introduction}

Resin composites are the most commonly used dental restorative materials. They are composed of organic matrix and inorganic filler and their properties can be modeled with addition of specific components. The literature provides data on various modifications of dental composites and adhesives performed to enhance their physico-chemical, mechanical and antimicrobial properties [1-5]. Antibacterial activity of monomers, such as 12-methacryloyloxydodecylpyridinium bromide (MDPB), has been widely investigated [5]. Among antibacterial agents introduced into the composition of dental resin materials, most commonly described in the literature are nanoparticles, such as silver, gold, titanium dioxide, zinc oxide or calcium phosphate, as well as fluoride-containing filler and fluoride compounds [6-12]. Essential oils (EOs) could be promising alternative to contribute to the antimicrobial effect of resin composite materials [13,14]. 
Essential oils are natural, volatile complex compounds characterized by the odor of their corresponding aromatic plants [15]. There is no systematic chemical nomenclature for chemical compounds found in EOs. However, the scientific names are based on their properties or prominent sources (e.g., limonene, pinene and thymol) [16-18]. They exhibit hydrophobic nature and often lower density in comparison to water and are generally lipophilic. Moreover, EOs are soluble in organic solvents, but immiscible with water [19].

EOs are plant products that for decades have been used in traditional healing worldwide. EOs are biosynthesized as secondary metabolites such as bark (cinnamon), buds (clove), flowers (jasmine, rose, violet and lavender), fruits (star anise), herbs, leaves (thyme, eucalyptus and salvia), twigs, wood (sandal), rhizome and roots (ginger), seeds (cardamom) and zest (citrus) [19]. EOs represent a small fraction of plant composition (less than $5 \%$ of the vegetal dry matter) and comprise mainly hydrocarbon terpenes (monoterpenes and sesquiterpenes) and terpenoids (isoprenoids). The chemical components of EOs may be produced through either the methylerythritol or the mevalonate or the shikimic acid pathway [19]. Over 100 different components in various ratios $(1 \%-70 \%)$ can be found in a single type of EO.

EOs exhibit different biological and pharmacological activities, such as antibacterial, antifungal, antiviral, antimutagenic, antiprotozoal, anti-inflammatory, antidiabetic, antinociceptive, antiphlogistic and antioxidant properties [20-30].

The combination of several EOs may lead to an additive or antagonistic effect against pathogens [31]. The enhanced antibacterial activity of EO mixture in comparison to individual products may result from the synergic effect of EO compounds. This effect relies either on inhibiting common biological pathway in microorganisms, suppressing the protective enzymes, or modifying the functions of the cellular wall [32]. EOs consist of different chemical compounds which may have different antimicrobial modes of action. Therefore, the possibility of antimicrobial resistance is minimized [17].

The mechanism of action of EOs against microorganisms has not been completely understood so far. EOs owe the antimicrobial properties to their volatile components, including terpenoids and phenolic compounds [33]. EO phenolic compounds are known to penetrate through the microbial membrane (formatting pores) leading to the leakage of ions and cytoplasmatic content and finally to cellular breakdown $[17,34]$.

In oral hygiene and dentistry, essential oils are used as components of mouthwashes (i.e., Cool Mint, Listerine Antiseptic, Johnson\&Johnson, Skillman, NJ, USA), toothpastes, antiseptic solutions and temporary filing materials (eugenol-based products, i.e., zinc oxide-eugenol cement) $[35,36]$. Incorporating essential oils into adhesive systems may contribute to the decrease in occurrence of secondary caries due to its antimicrobial activity reported in an in vitro microcosm dental biofilm model [14]. The main oral pathogens, Streptococcus mutans and Lactobacillus acidophilus are crucial in caries development. S. mutans plays main role in early demineralization of dental hard tissues, while L. acidophilus is pivotal in caries development. Various attempts has been made to enhance antibacterial properties of dental materials, involving the addition of silver-releasing filler [6,7], calcium fluoride [8,12] or amorphous calcium phosphate [9] into the composition of dental resin materials or adhesives. Studies reported that incorporation of essential oil into dental composite structure do not significantly compromise the mechanical properties [13,37], while it could improve its antibacterial activity and thus reduce the risk of secondary caries.

Yeasts, such as Candida albicans, are found in oral cavity as structural component of dental plaque biofilm, but more recently it has been recognized as part of cariogenic microbiota [38-41]. C. albicans is capable of producing acids that might demineralize dental hard tissues. According to Nikawa et al. [42], C. albicans possesses the ability to dissolve hydroxyapatite to a greater extent (approximately 20-fold) when compared with $S$. mutans. Furthermore, the presence of streptococci may promote C. albicans colonization of dental hard tissues [43]. Studies suggest symbiotic fungal-bacterial relationship between S. mutans and C. albicans within the biofilm that prevents from killing or inhibiting each other [44]. However, Maijala et al. [45] claimed that the role of $C$. albicans in cariogenic process is highly 
overestimated. Incorporating essential oils into dental materials composition seems like a promising alternative that would allow for enhancement of antimicrobial activity of dental restorative materials. In terms of potential anticariogenic effect, it would be favorable to investigate antimicrobial activity of various EOs against major cariogenic pathogens, such as S. mutans, L. acidophilus and C. albicans, in the same study, in homogeneous conditions. That would help to select the most active EOs in order to further incorporate them into dental materials composition to enhance their clinical performance. Thus, the primary aim of this study was to assess which of the different essential oils has the highest antimicrobial activity against oral pathogens (S. mutans, L. acidophilus and C. albicans). Next, the most effective essential oil would be selected to incorporate into resin material and the secondary aim of the study was to evaluate antimicrobial activity against S. mutans, L. acidophilus and C. albicans of the modified resin composite material.

\section{Materials and Methods}

This study used the following ten commercially available essential oils (dr Beta, Pollena Aroma, Nowy Dwór Mazowiecki, Poland): anise, cinnamon, citronella, clove, geranium, lavender, limette, mint, rosemary and thyme. The composition of tested EOs was presented in Table 1, based on data obtained from previous studies analyzing the EOs' composition by gas chromatography with flame-ionization and mass spectroscopic detection (GC-FID-MS) [46-52] or data from European Pharmacopoeia [53].

Table 1. Characteristics of essential oils used in the study.

\begin{tabular}{|c|c|}
\hline $\begin{array}{c}\text { Essential Oil } \\
\text { (Name of EO in INCI) }\end{array}$ & Composition \\
\hline $\begin{array}{c}\text { Star anise } \\
\text { (Illicium Verum Oil) }\end{array}$ & $\begin{array}{l}\text { trans-anethole }(86.0 \%-93.0 \%) \text {, linalool }(0.2 \%-2.5 \%) \text {, estragole } \\
(0.5 \%-6.0 \%), \alpha \text {-terpineol }(<0.3 \%), \text { cis-anethole }(0.1 \%-0.5 \%) \\
\text { anisaldehyde }(0.1 \%-0.5 \%) \text {, foeniculin }(0.1 \%-3.0 \%)[53]\end{array}$ \\
\hline $\begin{array}{c}\text { Cinnamon } \\
\text { (Cinnamomum Zeylanicum Bark Oil) }\end{array}$ & $\begin{array}{c}\text { cinnamaldehyde }(76.8 \%) \text {, methoxycinnamaldehyde }(11.7 \%) \text {, cinnamyl } \\
\text { acetate }(3.2 \%) \text {, cumarin }(1.5 \%) \text {, benzaldehyde }(1.1 \%)[48,49]\end{array}$ \\
\hline $\begin{array}{c}\text { Citronella } \\
\text { (Cymbopogon Winterianus Oil) }\end{array}$ & $\begin{array}{c}\text { citronellal (36.2\%), geraniol (22.4\%), citronellol (14.1\%), limonene }(3.5 \%) \text {, } \\
\text { elemol (3.3\%), citronellyl acetate }(3.2 \%)[51]\end{array}$ \\
\hline $\begin{array}{c}\text { Clove } \\
\text { (Eugenia Caryophyllus Oil) }\end{array}$ & eugenol (85.3\%), $\beta$-caryophyllene (10.6\%), $\alpha$-humulene $(2.0 \%)[47,49]$ \\
\hline $\begin{array}{c}\text { Geranium } \\
\text { (Pelargonium Graveolens Oil) }\end{array}$ & $\begin{array}{c}\text { citronellol }(26.7 \%) \text {, geraniol }(13.4 \%), \text { nerol }(8.7 \%) \text {, citronellyl formate } \\
(7.1 \%) \text {, isomenthone }(6.3 \%) \text {, linalool }(5.2 \%), 10-\text { epi- } \gamma \text {-eudesmol }(4.4 \%) \text {, } \\
\text { geranyl formate }(2.5 \%) \text {, menthone }(1.6 \%), \beta \text {-caryophyllene }(1.5 \%), \\
\text { geranyl butyrate, cis-rose oxide }(1.4 \%), \text { geranial }(1.1 \%), \beta \text {-baurobonene } \\
(1.1 \%)[47-49,52]\end{array}$ \\
\hline $\begin{array}{c}\text { Lavender } \\
\text { (Lavandula Angustifolia Oil) }\end{array}$ & $\begin{array}{c}\text { linalool (34.1\%), linalyl acetate }(33.3 \%) \text {, lavandulil acetate }(3.2 \%) \text {, } \\
\beta \text {-ocymene }(3.2 \%) \text {, } \beta \text {-caryophyllene }(2.7 \%) \text {, cineole }(2.5 \%) \text {, terpinen- } 4 \text {-ol } \\
\text { (2.5\%), myrecene }(2.4 \%), \alpha \text {-terpineol }(1.8 \%)[48,49]\end{array}$ \\
\hline $\begin{array}{c}\text { Limette } \\
\text { (Citrus aurantifolia oil) }\end{array}$ & $\begin{array}{c}\text { linalyl acetate }(48.06 \%) \text {, linalool }(26.88 \%) \text {, } \alpha \text {-terpineol }(5.74 \%) \text {, geranyl } \\
\text { acetate }(3.92 \%) \text {, geraniol }(3.05 \%) \text {, geranial }(2.44 \%)[50]\end{array}$ \\
\hline $\begin{array}{c}\text { Mint } \\
\text { (Mentha Piperita Oil) }\end{array}$ & $\begin{array}{c}\text { menthol }(30.0 \%-55.0 \%) \text {, menthone }(14.0 \%-32.0 \%) \text {, cineole }(3.5 \%-14.0 \%) \text {, } \\
\text { menthyl acetate }(2.8 \%-10.0 \%) \text {, isomenthone }(1.5 \%-10.0 \%) \text {, menthofuran } \\
(1.0 \%-9.0 \%) \text {, limonene }(1.0 \%-5.0 \%) \text {, isopulegol }(<0.2 \%) \text {, pulegone } \\
(<4.0 \%) \text {, carvone }(<1.0 \%)[53]\end{array}$ \\
\hline $\begin{array}{c}\text { Rosemary } \\
\text { (Rosmarinus Officinalis Oil) }\end{array}$ & $\begin{array}{c}\text { 1.8-cineole }(46.4 \%) \text {, camphor }(11.4 \%), \alpha \text {-pinene }(11.0 \%), \beta \text {-pinene }(9.2 \%) \text {, } \\
\text { camphene }(5.2 \%), \beta \text {-caryophyllene }(3.5 \%) \text {, borneol }(3.1 \%) \text {, } \alpha \text {-terpineol } \\
(1.8 \%), p \text {-cymene }(1.3 \%) \text {, myrecene }(1.2 \%)[47,49]\end{array}$ \\
\hline $\begin{array}{c}\text { Thyme } \\
\text { (Thymus Vulgaris Oil) }\end{array}$ & $\begin{array}{c}\text { thymol }(38.1 \%), p \text {-cymene }(29.1 \%), \gamma \text {-terpinene }(5.2 \%) \text {, linalool }(3.7 \%), \\
\beta \text {-Caryophyllene }(3.1 \%) \text {, carvacrol }(2.3 \%)[46,47,49]\end{array}$ \\
\hline
\end{tabular}

Legend: $\mathrm{INCI}=$ International Nomenclature of Cosmetic Ingredients. 


\subsection{Microbiological Studies of Essential Oils}

Microbiological studies were performed on three reference strains: Streptococcus mutans ATCC 25175 (Oxoid, Basingstoke, UK), Lactobacillus acidophilus ATCC 4356 (Oxoid, Basingstoke, UK) and Candida albicans ATTC 10231 (Biocorp, Warsaw, Poland). The colonies were stored in Microbank system (Viabank, Medical Wire\&Equipment, Corsham, UK) in the temperature of $-30{ }^{\circ} \mathrm{C}$ until the experiment was performed. The study protocol was described in detail in previous research paper [8].

Antimicrobial activity of essential oils was tested using agar diffusion test. After $18 \mathrm{~h}$ of cultivation, the suspension has been prepared with the turbidity of the $0.5 \mathrm{McFarland}$ standard and inoculated on Mueller-Hinton II Agar medium (Becton Dickinson, Franklin Lakes, NJ, USA) for S. mutans, on RPMI $1640+\mathrm{NaHCO}_{3}+$ L-Glutamine + phenol red medium (Biocorp, Warsaw, Poland) for C. albicans and media consisting of $90 \%$ IST (Oxoid, Basingstoke, UK) agar and 10\% MRS (Oxoid, Basingstoke, UK) agar adjusted to $\mathrm{pH} 6.7$ for L. acidophilus.

An automatic micropipette (Proline ${ }^{\circledR}$ Plus 2-20 $\mu$ L, Sartorius Biohit Liquid Handling Oy, Helsinki, Finland) was used to apply $6 \mu \mathrm{L}$ of tested essential oil on filter paper discs (Oxoid, Basingstoke, UK). Chlorhexidine digluconate ( $\mathrm{CHX}$ ) aqueous solution $(0.2 \%)$ served as a positive control. Filter paper discs (6 $\mathrm{mm}$ in diameter) were incubated for $20 \mathrm{~min}$ in room temperature in order to ensure the homogenous absorption of tested essential oil. Blank discs were used as negative control.

Next, sterile filter paper discs with tested oils, CHX and blank ones were placed directly on the inoculated agar surface. Special care was taken to ensure uniform contact of the paper disc with the media surface. The cultures were incubated for $18 \mathrm{~h}$ at temperature of $35^{\circ} \mathrm{C}$ : for S. mutans in $\mathrm{CO}_{2}$ enriched conditions-GENbox $\mathrm{CO}_{2}$ (bioMerieux S.A., Marcy l'Etoile, France), for L. acidophilus in anaerobic conditions; GENbox anaer (bioMerieux S.A., Marcy l'Etoile, France), for C. albicans-in aerobic conditions. After the removal of paper discs, the inhibition growth zones were measured (without subtracting disc diameter). For each tested EO and CHX, twelve filter paper discs were used to measure inhibition growth zone of every tested strain.

\subsection{Microbiological Studies of Composite Resin Material Modified with Essential Oil}

The chosen essential oil was introduced into flowable bulk-fill composite resin (CR) material (SDR flow, Dentsply Sirona, Konstanz, Germany) and mixed mechanically until obtaining uniform and homogenous consistency. The essential oils and dimetacrylate resins possess hydrophobic features hence they can be easily mixed to obtain homogeneous material. The material was modified with the essential oil that exhibited the highest antimicrobial activity. The concentrations of the essential oil were chosen as follows: Group 1: $1 \mu \mathrm{L}$ of EO in $2 \mathrm{~g}$ of CR; Group 2: $2 \mu$ of EO in $2 \mathrm{~g}$ of CR; Group 3:5 $5 \mathrm{~L}$ of EO in $2 \mathrm{~g}$ CR.

Disc-shaped ( $3 \mathrm{~mm}$ of height and $6 \mathrm{~mm}$ in diameter) samples of composite resin material modified with essential oil were performed. Each sample was light-cured with halogen lamp (Megalux Soft-start, Mega-PHYSIC Gmbh \& Co. KG, Rastatt, Germany) according to the manufacturer's instruction (i.e., 20 s). To evaluate antimicrobial activity against S. mutans, L. acidophilus and C. albicans of essential oil modified composite resin (EO-CR) eluate method was used.

The samples were placed in $2.5 \mathrm{~mL}$ of $0.95 \% \mathrm{NaCl}$ solution and incubated for $24 \mathrm{~h}$ in temperature of $35^{\circ} \mathrm{C}$. Next, after removing tested samples from the eluate, serial dilutions of the tested microbial strains were prepared $\left(10^{-1}, 10^{-2}, 10^{-3}, 10^{-4}, 10^{-5}\right.$ and $\left.10^{-6}\right)$ by the introduction of $200 \mu \mathrm{L}$ of the strains into $1.8 \mathrm{~mL}$ of eluate. Strains were incubated for $18 \mathrm{~h}$.

The control group was a sample of composite resin material, not modified with essential oil, that was incubated in the same conditions as the study groups samples.

After the incubation, to evaluate bacterial susceptibility, $100 \mu \mathrm{L}$ of the control and $100 \mu \mathrm{L}$ of bacteria dilution (of each dilution) in eluate were cultivated as follows: S. mutans on $\mathrm{MH}$ agar medium (Becton-Dickinson, Franklin Lakes, NJ, USA) in $\mathrm{CO}_{2}$-enriched conditions-GENbox $\mathrm{CO}_{2}$ (bioMerieux S.A., Marcy l'Etoile, France); L. acidophilus in anaerobic conditions on GENbox anaer medium (bioMerieux S.A., Marcy l'Etoile, France), and C. albicans in aerobic conditions on RPMI 
1640 medium (Thermo Fisher Scientific, Waltham, MA, USA). The strains were incubated for $24 \mathrm{~h}$ in temperature of $35^{\circ} \mathrm{C}$.

Upon the cultivation period, bacterial colonies in the studied samples and the control group were counted. The experiment was repeated twelve times for each EO-CR group and for the control group.

\subsection{Statistical Analysis}

The descriptive analysis of numerical variables encompasses the calculation of the mean (M) along with standard deviations (SD) values. The statistical analysis of the significance consisted of the following: Shapiro-Wilk W test for normality; Levene's tests for equality of variances; One-way analysis of variance; Kruskal-Wallis equality-of-populations rank test; Post-hoc multiple comparison tests; Zero-inflated Poisson regression with robust standard errors. A level of $p<0.05$ was deemed statistically significant. The statistical analyses of were carried out using Stata ${ }^{\circledR} /$ Special Edition, release 14.2 (StataCorp LP, College Station, TX, USA). The post-hoc statistical power was calculated using post-hoc power analysis calculator (https://clincalc.com/stats/Power.aspx) and a statistical power of $98.56 \%$ was found.

\section{Results}

\subsection{Antimicrobial Activity of Essential Oils (Inhibition Growth Zone)}

Figure 1 shows a measurement of representative inhibition growth zone of tested EO. The inhibition growth zones of tested microbes measured for each essential oil were presented in Figures 2-4. All tested essential oils, with exception to anise and limette EOs, were found to possess antibacterial activity against $S$. mutans (Figure 2). The diameter of the inhibition zone of $S$. mutans ranged from $0 \mathrm{~mm}$ for anise and limette essential oils up to $40 \mathrm{~mm}$ for cinnamon essential oil.

The cinnamon oil showed significantly highest antibacterial activity among all ten tested essential oils. Next, it was the thyme EO that exhibited significantly higher activity than anise, citronella, clove, geranium, lavender, limette, mint and rosemary EOs, but significantly lower than the cinnamon EO. Clove and lavender EOs exhibited antibacterial activity comparable to the one of $0.2 \%$ CHX. Citronella, geranium and mint showed significantly lower activity than other EOs, with exception to anise and limette EOs (Table A1). The latter showed the lowest antibacterial activity against S. mutans among all EOs tested.

All tested essential oils were found to possess antibacterial activity against L. acidophilus (Figure 3).

The diameter of the inhibition zone of L. acidophilus bacteria ranged from 8 to $40 \mathrm{~mm}$. Again, significantly highest antibacterial activity among all tested essential oils showed cinnamon and thyme EOs, followed by anise and citronella EOs. Geranium, mint EOs and CHX showed significantly higher activity than lavender, limette and rosemary EOs, but significantly lower-than anise, cinnamon, citronella, clove and thyme EOs (Table A2). Lavender and rosemary EOs exhibited the significantly lowest antibacterial activity.

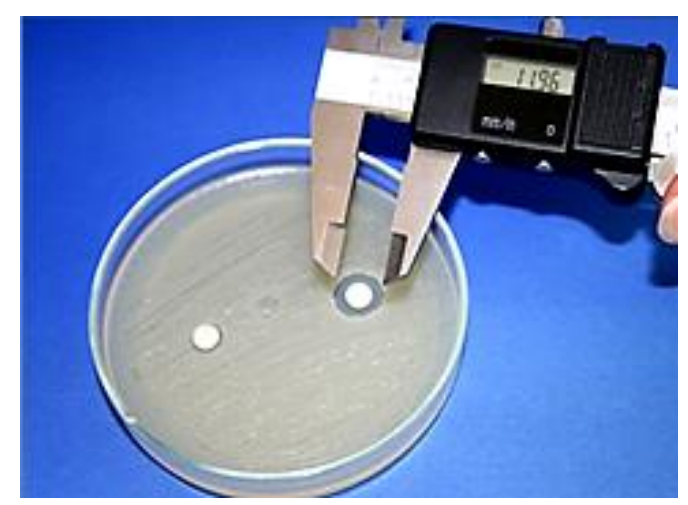

Figure 1. Representative figure of measurement of growth inhibition zone. 


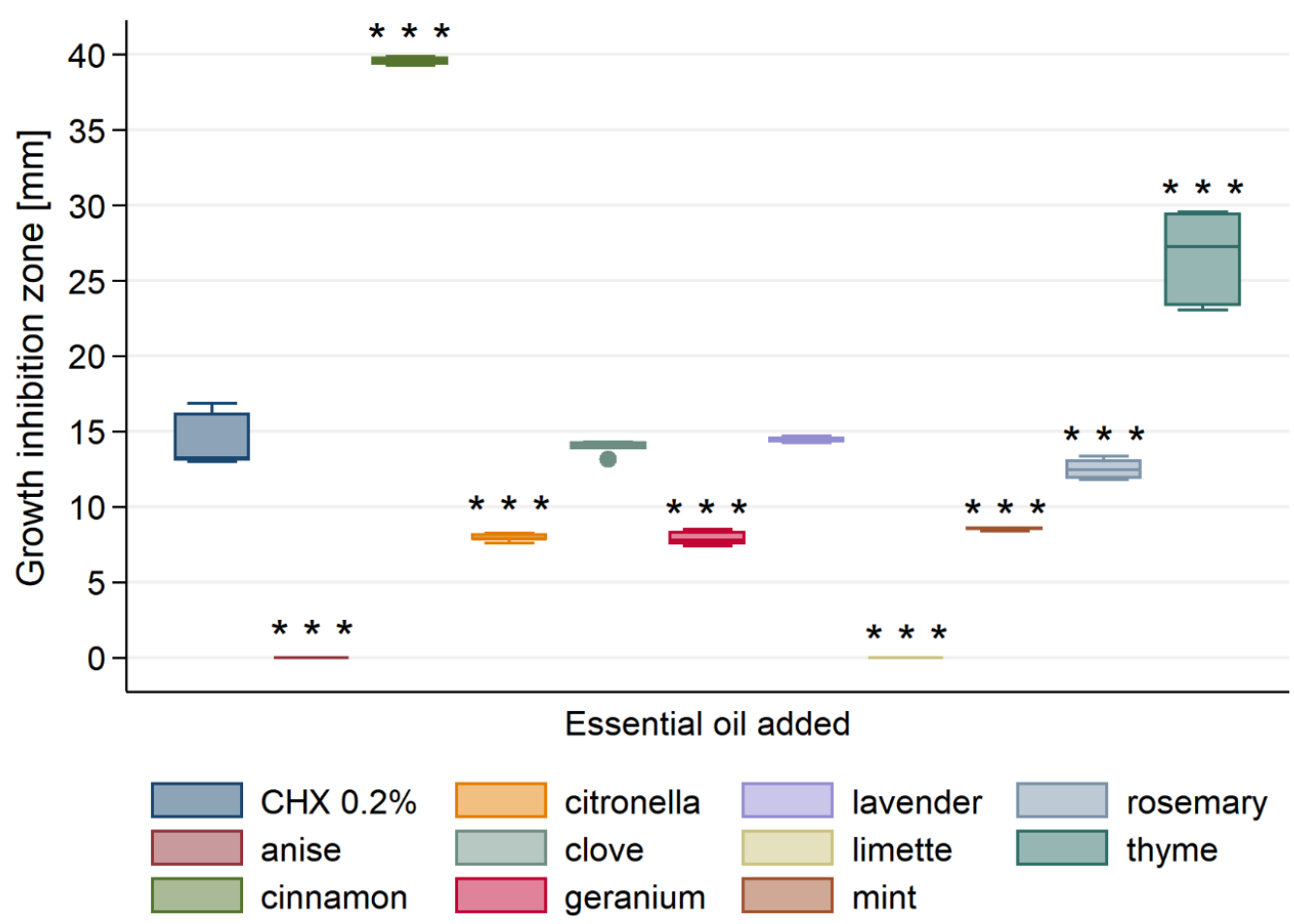

Figure 2. Antibacterial activity of tested essential oils against $S$. mutans. ${ }^{* * *} p<0.001$ versus positive control $(0.2 \% \mathrm{CHX})$.

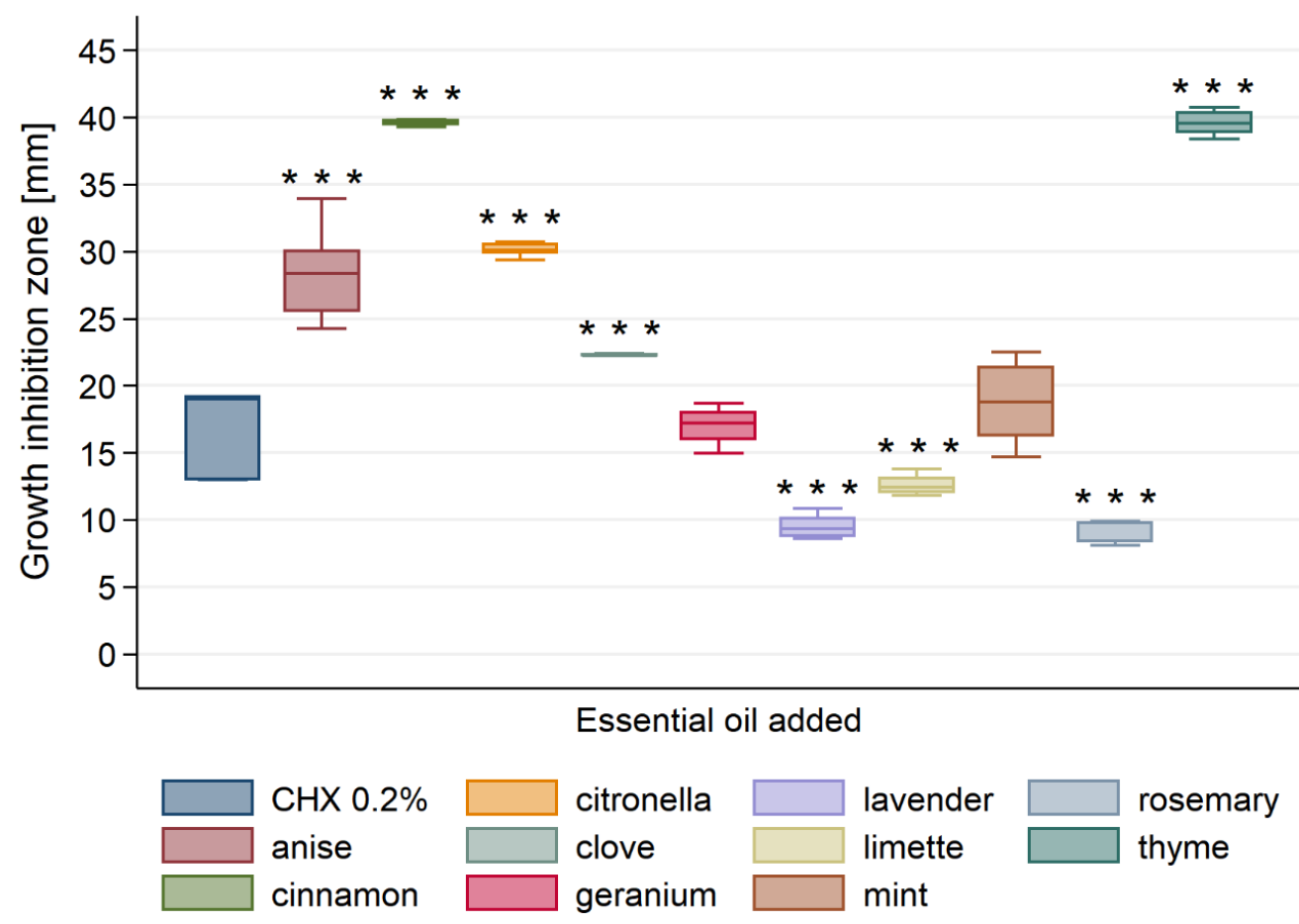

Figure 3. Antibacterial activity of tested essential oils against L. acidophilus. ${ }^{* * *} p<0.001$ versus positive control $(0.2 \% \mathrm{CHX})$. 


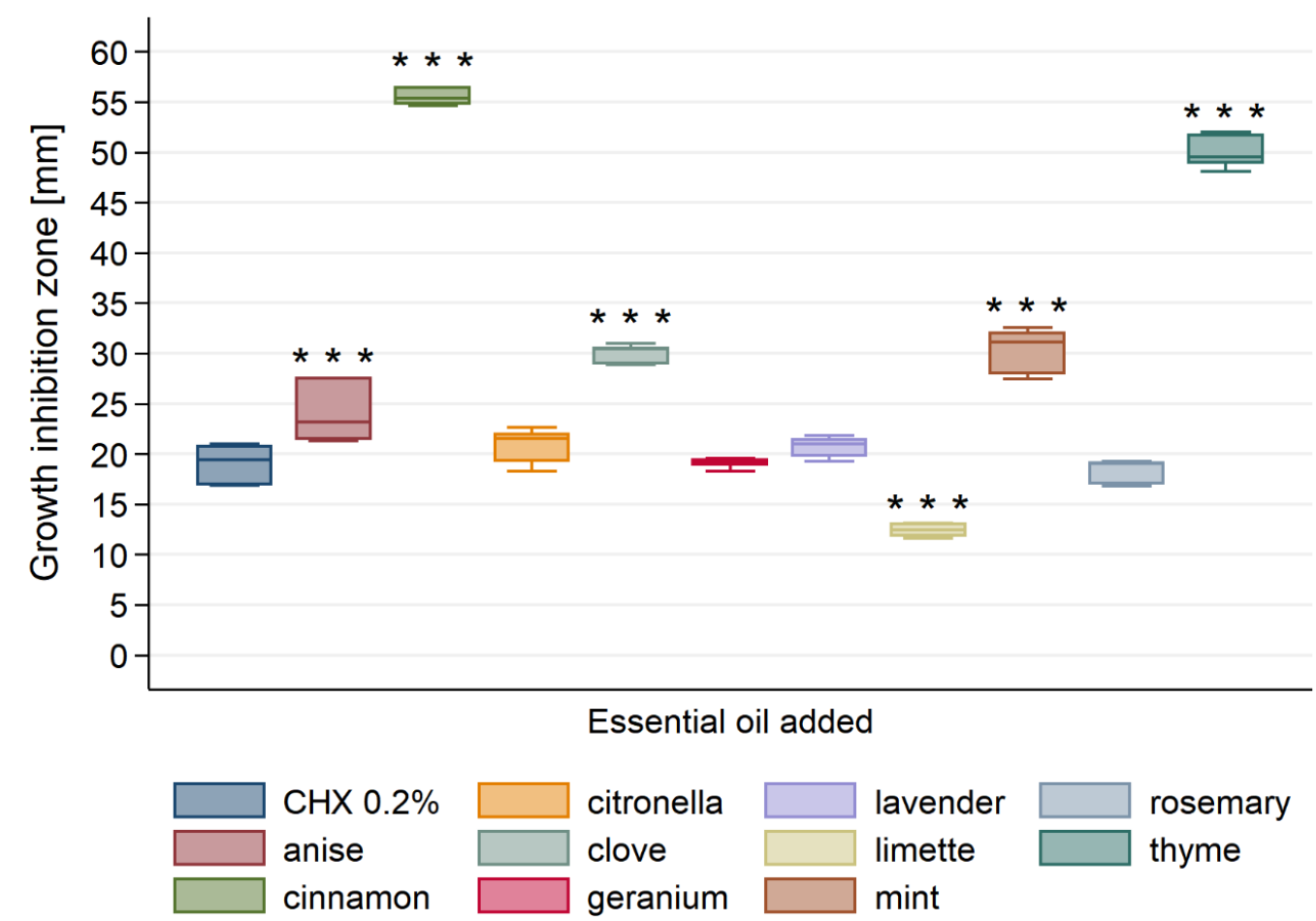

Figure 4. Antifungal activity of tested essential oils against C. albicans. ${ }^{* * *} p<0.001$ versus positive control $(0.2 \% \mathrm{CHX})$.

All tested essential oils were found to possess antifungal activity (Figure 4). The diameter of the inhibition zone of C. albicans ranged from 12 to $56 \mathrm{~mm}$.

The significantly highest antifungal activity among all tested essential oils showed cinnamon EO, followed by thyme EO. Clove and mint EOs showed significantly higher activity than other EOs (with exception to cinnamon and thyme EOs). Citronella, geranium and lavender EOs exhibited significantly lower activity than anise, cinnamon, clove, mint and thyme EOs (Table A3). CHX possessed similar antifungal activity as citronella and lavender EOs. Limette exhibited the significantly lowest antifungal activity among all tested EOs.

\subsection{Antimicrobial Activity of Composite Resin Modified with Essential Oil}

The highest antimicrobial activity against all tested pathogens showed cinnamon EO, hence it was introduced into composite resin material. Next, the modified material was tested for antimicrobial activity against oral pathogens, i.e., S. mutans, L. acidophilus and C. albicans.

For all tested microbes, the essential oil modified composite resins showed statistically significant different CFU than for the control group regardless of the EO concentration (Figures 5-7). Antimicrobial activity of EO-CRs was significantly higher than that of unmodified CR. Furthermore, Fisher's post-hoc test revealed, that for each tested oral pathogen, the differences in CFU between the study groups were statistically significant.

As for S. mutans, the significantly highest antibacterial activity showed $2 \mu \mathrm{L} / 2 \mathrm{~g}$ EO-CR, followed by $1 \mu \mathrm{L} / 2 \mathrm{~g}$ EO-CR and $5 \mu \mathrm{L} / 2 \mathrm{~g}$ EO-CR $(p<0.001)$. Whereas, for L. acidophilus the least CFU were noted for $1 \mu \mathrm{L} / 2 \mathrm{~g}$ EO-CR, followed by $2 \mu \mathrm{L} / 2 \mathrm{~g}$ EO-CR and $5 \mu \mathrm{L} / 2 \mathrm{~g}$ EO-CR $(p<0.001)$.

As far as antifungal activity against $C$ albicans was concerned, the highest activity showed $2 \mu \mathrm{L} / 2 \mathrm{~g}$ EO-CR and the lowest $5 \mu \mathrm{L} / 2 \mathrm{~g}$ EO-CR $(p<0.001)$. 


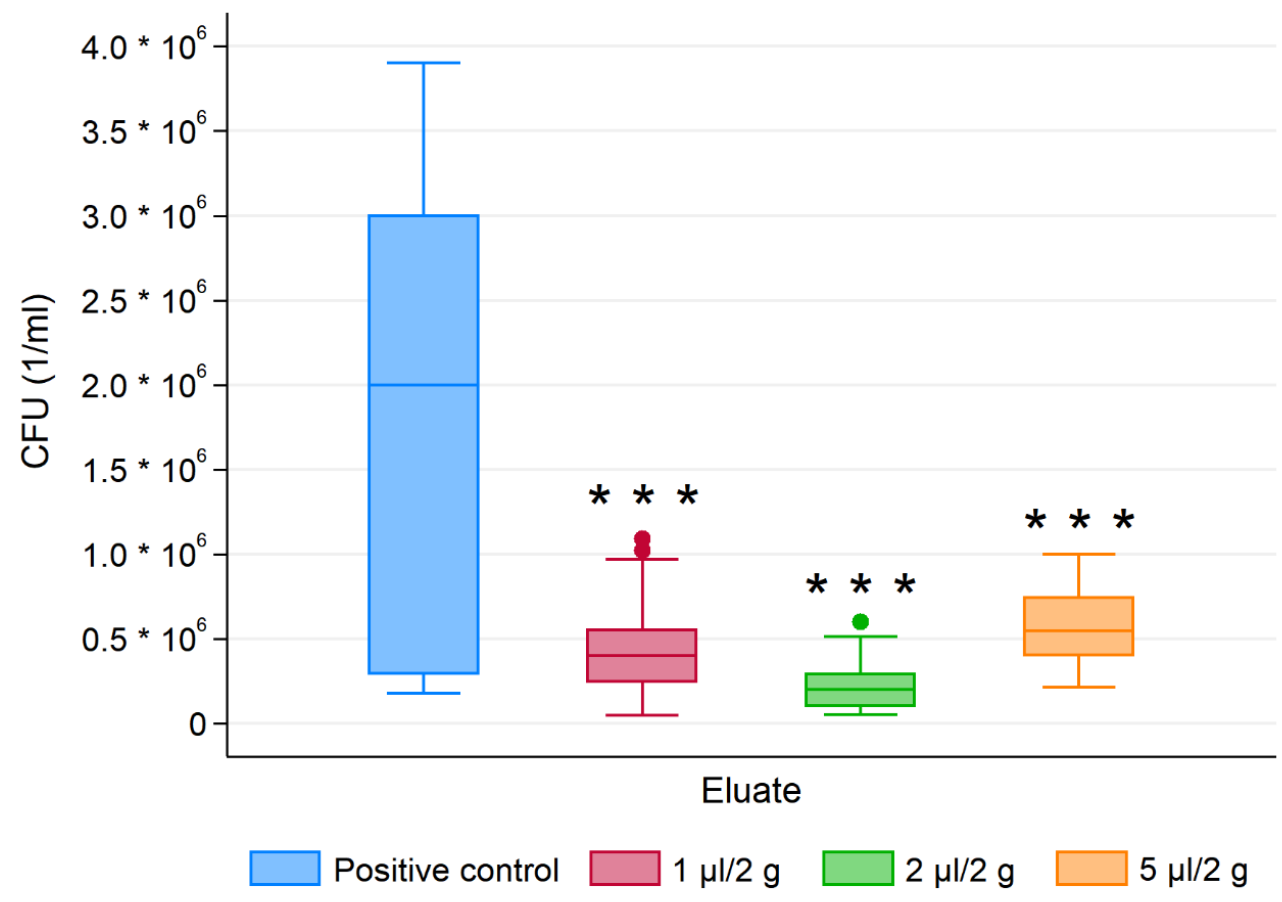

Figure 5. Colony forming units (CFU) of $S$. mutans for essential oil modified composite resins and the control group. ${ }^{* * *} p<0.001$ versus control.

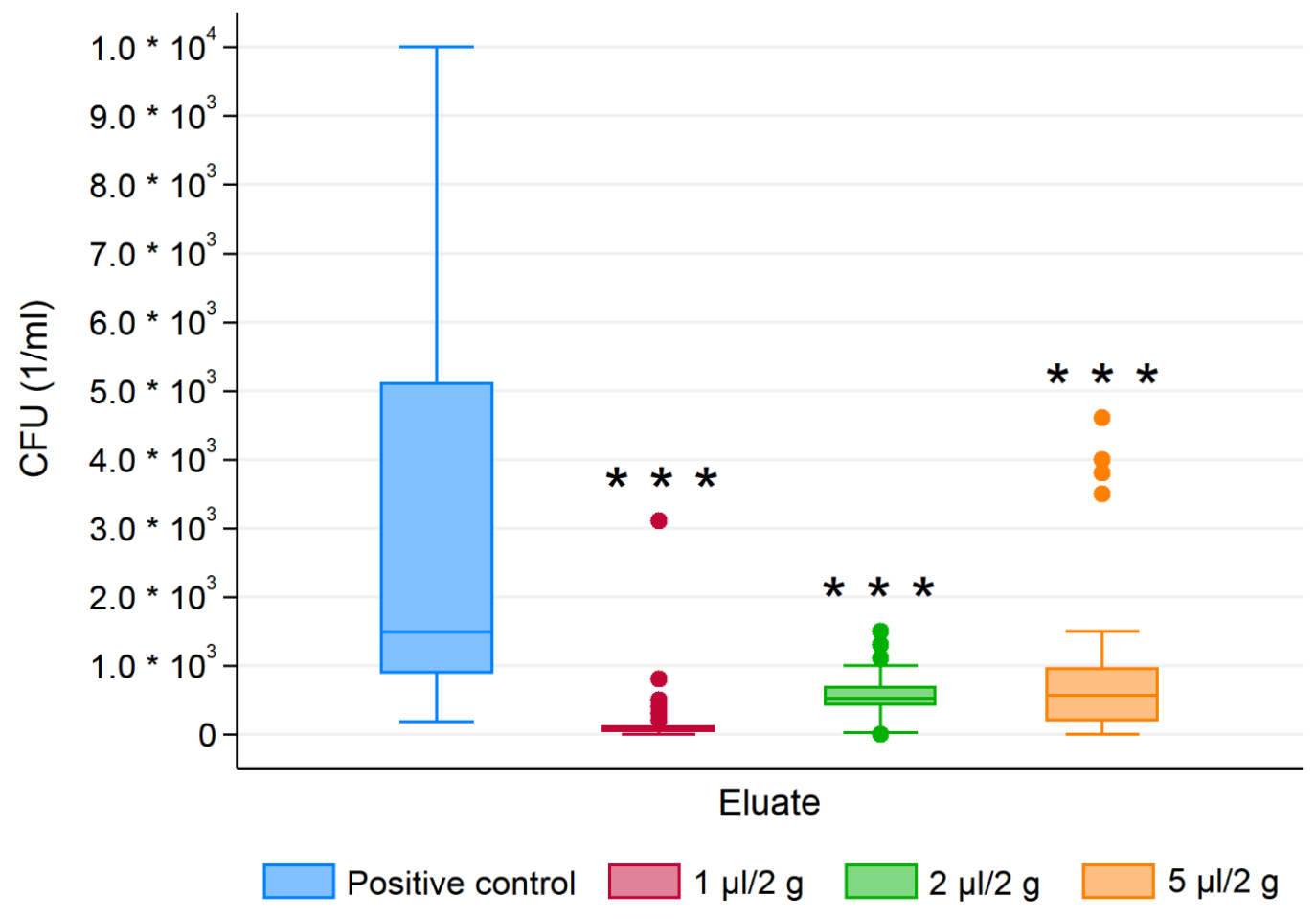

Figure 6. Colony forming units (CFU) of L. acidophilus for essential oil modified composite resins and the control group. ${ }^{* * *} p<0.001$ versus control. 


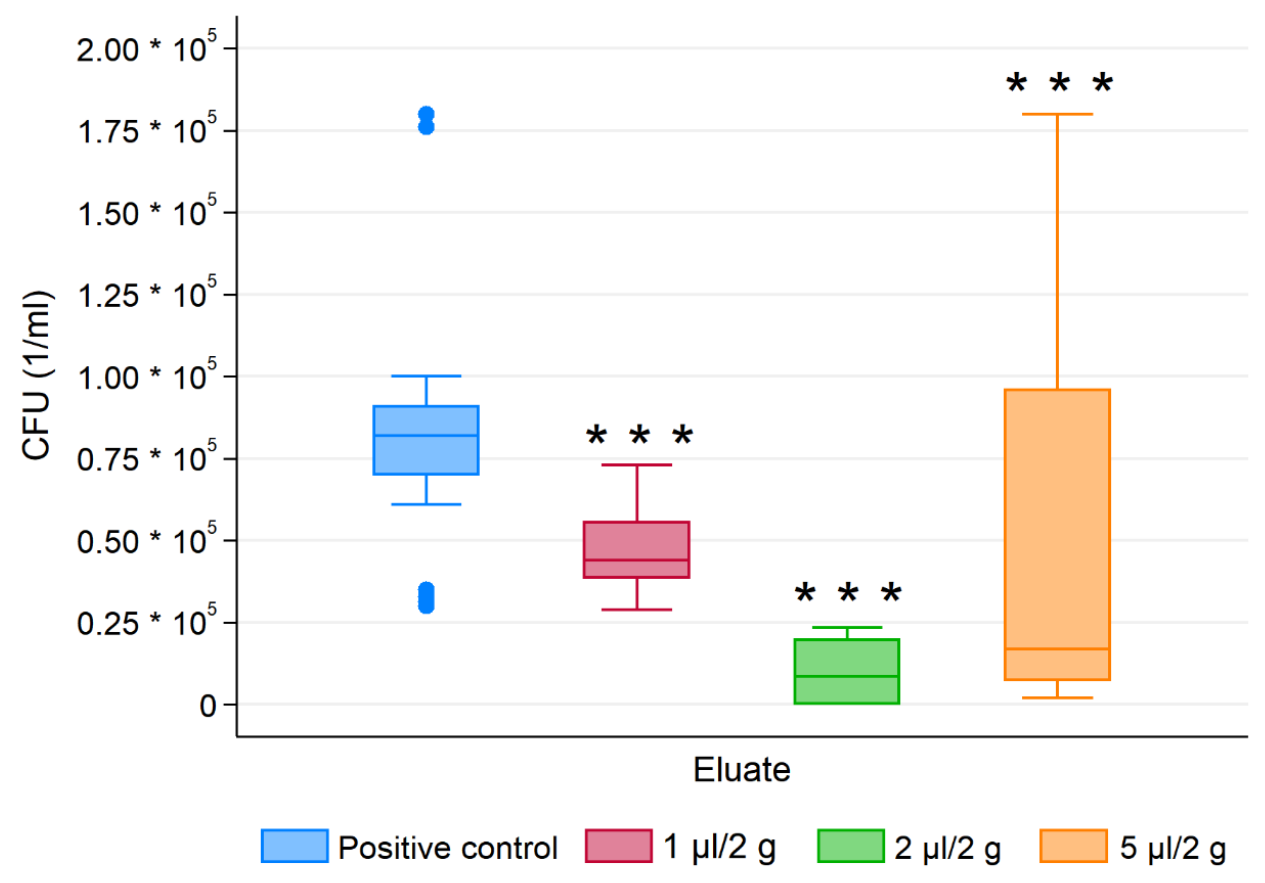

Figure 7. Colony forming units (CFU) of $C$. albicans for essential oil modified composite resins and the control group. ${ }^{* * *} p<0.001$ versus control.

\section{Discussion}

Essential oils have been used in many walks of life, including dentistry. Researchers constantly search for new possibilities of application of effective formulas into dental products. EOs seem to be the promising ingredients of future oral care products and dental materials used both by patients and dentists. The present study investigated antibacterial activity of ten essential oils against three cariogenic pathogens: S. mutans, L. acidophilus and C. albicans. Such great variety of essential oils tested in one study seemed advantageous as the experiment was performed in the same standardized conditions and allowed for reliable assessment and comparison of EOs' antimicrobial properties. As far as oral pathogens are concerned, most of the previous studies described only a few essential oils $[13,14,37,54,55]$ against one or two most cariogenic bacteria in one setting $[56,57]$.

In the present study, among ten tested essential oils, the most prominent antimicrobial activity exhibited two EOs: cinnamon and thyme. The other EO that showed both significant antibacterial and antifungal effect was clove oil. These results confirmed other findings that EOs possessed potent antibacterial activity and antifungal properties against oral pathogens, including cariogenic bacteria [54,56-58]. The study used S. mutans and L. acidophilus, due to their undisputable involvement in the carious process. The former one is responsible for the initiation of the process and the latter for its development [59-61]. Given their proven cariogenic activity, S. mutans as well as Lactobacillus spp., have been used in the present study. In addition, C. albicans is considered to play a supportive role in cariogenic process [42]. Similarly to other studies [62], current study used $0.2 \%$ chlorhexidine digluconate aqueous solution as a positive control due to its proved antimicrobial and antifungal activity $[63,64]$.

The composition of EOs determines their antibacterial potential. The highest activity of EOs is provided by thymol, eugenol and carvacrol content, followed by alcohol-containing EOs, with alcohols such as citronellol, geraniol, linalool, menthol, terpinen-4-ol and $\alpha$-terpineol. Another bioactive group comprise of EOs that contain either ketones, e.g., camphor, carvone, menthone, or thujene or aldehyde groups, i.e., cinnamaldehyde, as well as those with other functional groups, such as anethole and cineole. 
Cinnamon essential oil has high percentage of aldehydes (cinnamon aldehydes), that possess antifungal, anti-inflammatory and disinfectant qualities [65]. The effectiveness of cinnamon EO and cinnamon aldehyde against $S$. mutans, $S$. mitis, $S$. salivarius, $A$. actinomycetemcomitans, $P$. gingivalis and Fusobacterium nucleatum was reported by Zainal-Abidin et al. [66]. Other studies also confirmed antibacterial activity of cinnamon $[47,67]$ and clove $[47,68,69]$ essential oils against S. mutans. High antibacterial activity of clove EOs depends on its aromatic compound content: eugenol (85.3\%). Eugenol was reported to have antiseptic, antimicrobial, anesthetic, analgesic, antioxidant, anti-inflammatory and cardiovascular activities [70]. In the present study, cinnamon EO showed significantly higher antimicrobial activity than clove EO, which is consistent with other study [69]. Clove and cinnamon were found to inhibit fungal growth at a concentration of $6 \%$ [57]. The results of the present study are consistent with other findings [71] reporting cinnamon oil to have the most potential antibacterial properties. Another study [72] proved cinnamon essential oil to possess the highest antibacterial activity against $S$. mutans among other nine oils (eucalyptol, lime, clove, mint, vinegar, cedar and citrus grass). In addition, Arora and Kaur [73] observed the antimicrobial activity of clove EO against $C$. albicans. It was confirmed by the present study, in which clove EOs exhibited significantly higher activity against $C$. albicans and L. acidophilus than $\mathrm{CHX}$, whereas no significant difference between in activity of clove $\mathrm{EO}$ and $\mathrm{CHX}$ against $S$. mutans was found.

Thyme EO was reported to show antimicrobial activity against oral pathogens due to high content of thymol $(38.1 \%)$ and $p$-cymene $(29.1 \%)[47,74]$. Phenolic compound-thymol, the main component of thyme EO-is reported to disintegrate the outer membrane of Gram-negative bacteria and make bacterial cytoplasmic membrane more permeable to ATP [75]. Another constituent of thyme EO-carvacrol-is proved to exhibit antibacterial potential against S. mutans and C. albicans [54,62]. Carvacrol emulsion might be also a promising alternative to $\mathrm{NaOCl}$ in irrigation of dental root canal system and eradication of intracanal bacteria: E. feacalis [76]. Studies proved also a potent antimicrobial activity of thymol against $S$. mutans and $C$. albicans $[54,57]$, as well as against Porphyromonas gingivalis and A. actinomycetemcomitans, which play a role in development of periodontal disease [77]. That was confirmed by the present study. Thyme EO exhibited the significantly highest antimicrobial activity against $C$. albicans and S. mutans, whereas the antibacterial activity against $L$. acidophilus was significantly higher than of other EOs, but lower than that of cinnamon EO. Another study stated that clove, thyme, cinnamon and peppermint EOs are potent antimicrobial phenols [17].

Other EOs tested in the study, such as citronella, geranium, lavender, limette, mint, rosemary presented medium antibacterial activity that is associated with the content of citronellol and geraniol, linalool and linalyl acetate, 1.8-cineole, camphor and $\alpha$-pinene [74]. As for anise EO, it showed no antibacterial activity against $S$. mutans, whereas its activity against L. acidophilus and antifungal activity were high. Antifungal potential of this EO can be attributed to high content of trans-anethole, which can interact with fungal plasma [78].

The positive correlation between antibacterial activity of EOs and high content of certain components was reported only for few EOs (e.g., mint, thyme and oregano). For others (e.g., limette and lavender), it is most likely that their antibacterial potential is the result of synergistic effect of the components, since some of those major components exhibit higher antibacterial effect than the EO itself [79].

The present study proved that cinnamon and thyme followed by clove EOs exhibited significantly higher or equal antimicrobial properties against oral pathogens than CHX. These findings would be the introduction to further investigations aiming at the incorporation of these oils into oral care products, i.e., tooth pastes, mouth rinses. The antimicrobial potential of these EOs might be also used to enhance the antibacterial properties of dental materials such as dental resin materials, temporary dressings, disinfectants or root canal filling materials. Furthermore, extracting the most active components from EOs and introducing them into dental products (e.g., restorative materials) composition might be promising line of research. The abundance literature reported that there is great need for development of dental materials with antibacterial properties $[4,8,10,12,55,80]$. The results of previous studies 
on antibacterial properties of dental materials seemed promising and suggested that introducing antimicrobial agents into the composition of dental materials might improve their antibacterial potential without deteriorating the physico-mechanical performance $[8,12,37]$.

Given the highest antimicrobial activity obtained in the present study, cinnamon essential oil was used to incorporate, in three different concentrations, into composite resin material composition. Based on preliminary experiments performed, the tested concentration of the EO in composite resin was established as 1,2 or $5 \mu \mathrm{L}$ of EO in $2 \mathrm{~g}$ of CR. The best antimicrobial properties against S. mutans and C. albicans were achieved for composite resin containing this essential oil in concentration $2 \mu \mathrm{L} / 2 \mathrm{~g}$, whereas against $L$. acidophilus in concentration $1 \mu \mathrm{L} / 2 \mathrm{~g}$. Ideally, the composite resin material would present antimicrobial effect and possess very good mechanical properties. The addition of antibacterial or antifungal agents should not change the mechanical performance of the resin material. The current experiment showed that the addition of $2 \mu \mathrm{L}$ of cinnamon essential oil into $2 \mathrm{~g}$ of composite material allows for limiting microbial growth of tested oral pathogens in comparison to unmodified material. This composition might be optimal in terms of antimicrobial properties due to mild influence on polymerization process and enabling release of active compounds into environment.

Still, the present study has some limitations. First of all, the study used single-species model with isolated strains of specific oral pathogens tested in in vitro conditions, without saliva involvement, whereas oral cavity is complex environment holding variety of pathogens interacting in formation of oral biofilm on hard dental tissues. Therefore, these findings must be confirmed in further microbiological studies.

Next, mechanical properties of composite resins modified with essential oils should be tested if considering such materials for clinical application. One study [13] tested mechanical properties of composite resin material modified with cinnamon EO, such as hardness, tensile and flexural strength. The results of the study provided inconsistent data on the proper concentration of the EO in the CR to obtain desirable mechanical performance of the EO-CR material. However, the addition of cinnamon EO to composite material did not adversely affect all the mechanical properties. CR material showed significantly higher flexural strength when modified with $1 \mu \mathrm{L}$ of cinnamon EO (in $2 \mathrm{~g}$ of the material) than non-modified CR. In contrast, non-modified CR showed significantly higher hardness (HV1) and tensile strength values in comparison to modified CR. As far as tensile strength of EO-CR material was concerned, the addition of $2 \mu \mathrm{L}$ of cinnamon EO (in $2 \mathrm{~g}$ of the material) allowed for obtaining significantly highest results. On the contrary, the addition of high amount of EO (5 $\mu \mathrm{L} / 2 \mathrm{~g})$ significantly deteriorated all tested mechanical properties. Still, such EO-modified bulk-fill material could be clinically used in pediatric dentistry as a final filling in primary teeth or in permanent teeth as a temporary filling, as a liner or in two-step bulk restorative technique in deep cavities. Furthermore, class V cavities, with minimum occlusal loading could be restored with such composite material. Still, long-term performance of such restorations and their aesthetic features must be evaluated.

Moreover, long term study should be performed to evaluate possible allergic reaction to essential oil modified composite resin material as well as the cytotoxic effect of EOs released from EO-CRs. Study showed that EOs present cytotoxic effects on living cells and the severity depends on their type and concentration [16]. Hence, further studies should be conducted to evaluate the potential cytotoxicity and long-term antimicrobial effect of essential oils incorporated into the dental restorative materials.

Since the present study tested only one restorative material, the results cannot be translated to other composites resin materials due to some variation in their composition.

\section{Conclusions}

The study showed that all ten tested essential oils possess antibacterial activity against L. acidophilus and antifungal activity against C. albicans. Only two essential oils, anise and limette were ineffective towards S. mutans. Among tested essential oils, the cinnamon and thyme showed overall the highest antibacterial and antifungal activity against oral pathogens used in the study. Composite resin modified with cinnamon essential oil showed antimicrobial effect regardless of the EO concentration. 
Considering these preliminary results, essential oils seem promising alternative to other antibacterial agents incorporated into resin composite and further studies should be conducted to further evaluate the antimicrobial effect of dental composites modified with essential oils, as well as their mechanical properties.

Author Contributions: Conceptualization, M.L.-S. and A.S.; methodology, B.Z.; software, B.Z.; validation, A.S., B.Z. and J.G.; formal analysis, A.S.; investigation, A.S.; resources, J.S.; data curation, A.S. and B.L.; writing —original draft preparation, A.S., M.L.-S. and B.L.; writing-review and editing, B.L., L.H. and M.L.-S.; visualization, B.L.; supervision, M.L.-S.; project administration, M.L.-S.; funding acquisition, J.S. All authors have read and agreed to the published version of the manuscript.

Funding: This research received no external funding.

Conflicts of Interest: The authors declare no conflict of interest.

\section{Appendix A}


Table A1. Levels of statistical significance ( $p$ ) in Fisher's post-hoc test of EOs activity against S. mutans.

\begin{tabular}{|c|c|c|c|c|c|c|c|c|c|c|}
\hline Essential Oil & Anise & Citronella & Cinnamon & Clove & Geranium & Lavender & Limette & Mint & Rosemary & Thyme \\
\hline $\begin{array}{c}\text { Anise } \\
\text { Citronella }\end{array}$ & & NS & NS & NS & NS & NS & NS & $\begin{array}{c}\text { NS } \\
0.688\end{array}$ & NS & NS \\
\hline Cinnamon & & $<0.001$ & & $<0.001$ & & $<0.001$ & & $<0.001$ & $<0.001$ & \\
\hline Clove & & $<0.001$ & & & & 0.157 & & $<0.001$ & & \\
\hline Geranium & & 0.905 & $<0.001$ & $<0.001$ & & $<0.001$ & NS & 0.604 & $<0.001$ & $<0.001$ \\
\hline Lavender & & $<0.001$ & & & & & & $<0.001$ & & \\
\hline $\begin{array}{l}\text { Limette } \\
\text { Mint }\end{array}$ & & NS & NS & NS & & NS & & NS & NS & \\
\hline Rosemary & & $<0.001$ & & 0.181 & & 0.940 & & $<0.001$ & & \\
\hline Thyme & & $<0.001$ & $<0.001$ & $<0.001$ & & $<0.001$ & NS & $<0.001$ & $<0.001$ & \\
\hline
\end{tabular}

NS = not significant

Table A2. Levels of statistical significance $(p)$ in Fisher's post-hoc test of EOs activity against L. acidophilus.

\begin{tabular}{|c|c|c|c|c|c|c|c|c|c|c|}
\hline Essential oil & Anise & Cinnamon & Citronella & Clove & Geranium & Lavender & Limette & Mint & Rosemary & Thyme \\
\hline Anise & & $<0.001$ & 0.544 & $<0.001$ & $<0.001$ & $<0.001$ & $<0.001$ & $<0.001$ & $<0.001$ & $<0.001$ \\
\hline Cinnamon & & & $<0.001$ & $<0.001$ & & $<0.001$ & & $<0.001$ & $<0.001$ & \\
\hline Citronella & & & & & & & & $<0.001$ & & \\
\hline Clove & & & $<0.001$ & & & $<0.001$ & & $<0.001$ & & \\
\hline Geranium & & $<0.001$ & $<0.001$ & $<0.001$ & & $<0.001$ & $<0.001$ & 0.209 & $<0.001$ & $<0.001$ \\
\hline Lavender & & & $<0.001$ & & & & & $<0.001$ & & \\
\hline $\begin{array}{l}\text { Limette } \\
\text { Mint }\end{array}$ & & $<0.001$ & $<0.001$ & $<0.001$ & & $<0.001$ & & $<0.001$ & $<0.001$ & \\
\hline Rosemary & & & $<0.001$ & $<0.001$ & & 0.557 & & $<0.001$ & & \\
\hline Thyme & & 0.734 & $<0.001$ & $<0.001$ & & $<0.001$ & $<0.001$ & $<0.001$ & $<0.001$ & \\
\hline
\end{tabular}


Table A3. Levels of statistical significance $(p)$ in Fisher's post post-hoc test of EOs activity against C. albicans

\begin{tabular}{|c|c|c|c|c|c|c|c|c|c|c|}
\hline Essential oil & Anise & Cinnamon & Citronella & Clove & Geranium & Lavender & Limette & Mint & Rosemary & Thyme \\
\hline Anise & & $<0.001$ & $<0.001$ & $<0.001$ & $<0.001$ & $<0.001$ & $<0.001$ & $<0.001$ & $<0.001$ & $<0.001$ \\
\hline Cinnamon & & & $<0.001$ & $<0.001$ & & $<0.001$ & & $<0.001$ & $<0.001$ & \\
\hline Citronella & & & & & & & & $<0.001$ & & \\
\hline Clove & & & $<0.001$ & & & $<0.001$ & & 0.486 & & \\
\hline Geranium & & $<0.001$ & 0.030 & $<0.001$ & & 0.001 & $<0.001$ & $<0.001$ & 0.648 & $<0.001$ \\
\hline Lavender & & & 0.252 & & & & & $<0.001$ & & \\
\hline $\begin{array}{c}\text { Limette } \\
\text { Mint }\end{array}$ & & $<0.001$ & $<0.001$ & $<0.001$ & & $<0.001$ & & $<0.001$ & $<0.001$ & \\
\hline Rosemary & & & 0.009 & $<0.001$ & & $<0.001$ & & $<0.001$ & & \\
\hline Thyme & & $<0.001$ & $<0.001$ & $<0.001$ & & $<0.001$ & $<0.001$ & $<0.001$ & $<0.001$ & \\
\hline
\end{tabular}




\section{References}

1. Beyth, N.; Farah, S.; Domb, A.J.; Weiss, E.I. Antibacterial dental resin composites. React. Funct. Polym. 2014, 75, 81-88. [CrossRef]

2. Lukomska-Szymanska, M.; Konieczka, M.; Zarzycka, B.; Lapinska, B.; Grzegorczyk, J.; Sokolowski, J. Antibacterial activity of commercial dentine bonding systems against E. faecalis-flow cytometry study. Materials 2017, 10, 481. [CrossRef] [PubMed]

3. Lapinska, B.; Konieczka, M.; Zarzycka, B.; Sokolowski, K.; Grzegorczyk, J.; Lukomska-Szymanska, M. Flow cytometry analysis of antibacterial effects of universal dentin bonding agents on streptococcus mutans. Molecules 2019, 24, 532. [CrossRef] [PubMed]

4. Imazato, S. Bio-active restorative materials with antibacterial effects: New dimension of innovation in restorative dentistry. Dent. Mater. J. 2009, 28, 11-19. [CrossRef]

5. Cocco, A.R.; Rosa, W.L.D.O.D.; Silva, A.F.; Lund, R.G.; Piva, E. A systematic review about antibacterial monomers used in dental adhesive systems: Current status and further prospects. Dent. Mater. 2015, 31, 1345-1362. [CrossRef]

6. Barszczewska-Rybarek, I.; Chladek, G. Studies on the curing efficiency and mechanical properties of bis-GMA and TEGDMA nanocomposites containing silver nanoparticles. Int. J. Mol. Sci. 2018, 19, 3937. [CrossRef]

7. Stencel, R.; Kasperski, J.; Pakiela, W.; Mertas, A.; Bobela, E.; Barszczewska-Rybarek, I.; Chladek, G. Properties of experimental dental composites containing antibacterial silver-releasing filler. Materials 2018, 11, 1031. [CrossRef]

8. Lukomska-Szymanska, M.; Zarzycka, B.; Grzegorczyk, J.; Sokolowski, K.; Poltorak, K.; Sokolowski, J.; Lapinska, B. Antibacterial properties of calcium fluoride-based composite materials: In Vitro study. BioMed Res. Int. 2016, 2016, 1-7. [CrossRef]

9. Drzewiecka, K.; Kleczewska, J.; Krasowski, M.; Lapinska, B.; Sokolowski, J. The Influence of amorphous calcium phosphate addition on mechanical properties of the experimental light-cured dental composite. Dent. Med. Probl. 2016, 53, 34-40. [CrossRef]

10. Pokrowiecki, R.; Zareba, T.; Mielczarek, A.; Opalińska, A.; Wojnarowicz, J.; Majkowski, M.; Lojkowski, W.; Tyski, S. Evaluation of biocidal properties of silver nanoparticles against cariogenic bacteria. Med. Dosw. Mikrobiol. 2013, 65, 197-206.

11. Marović, D.; Šariri, K.; Demoli, N.; Ristić, M.; Hiller, K.-A.; Škrtić, D.; Rosentritt, M.; Schmalz, G.; Tarle, Z. Remineralizing amorphous calcium phosphate based composite resins: The influence of inert fillers on monomer conversion, polymerization shrinkage, and microhardness. Croat. Med. J. 2016, 57, 465-473. [CrossRef] [PubMed]

12. Lukomska-Szymanska, M.; Kleczewska, J.; Nowak, J.; Prylinski, M.; Szczesio, A.; Podlewska, M.; Sokolowski, J.; Lapinska, B. Mechanical properties of calcium fluoride-based composite materials. BioMed Res. Int. 2016, 2016, 1-8. [CrossRef]

13. Szram, A.; Sokolowski, J.; Nowak, J.; Domarecka, M.; Lukomska-Szymanska, M. Mechanical properties of composite material modified with essential oil. Inż. Mater. 2017, 1, 49-53. [CrossRef]

14. Peralta, S.L.; Carvalho, P.H.A.; van de Sande, F.H.; Pereira, C.M.P.; Piva, E.; Lund, R.G. Self-etching dental adhesive containing a natural essential oil: Anti-biofouling performance and mechanical properties. Biofouling 2013, 29, 345-355. [CrossRef] [PubMed]

15. Noorizadeh, H.; Farmany, A.; Noorizadeh, M. Quantitative structure-retention relationships analysis of retention index of essential oils. Quím. Nova 2011, 34, 242-249. [CrossRef]

16. Bakkali, F.; Averbeck, S.; Averbeck, D.; Idaomar, M. Biological effects of essential oils-A review. Food Chem. Toxicol. 2008, 46, 446-475. [CrossRef]

17. Burt, S. Essential oils: Their antibacterial properties and potential applications in foods-Review. Int. J. Food Microbiol. 2004, 94, 223-253. [CrossRef]

18. Carson, C.F.; Hammer, K.A. Chemistry and bioactivity of essential oils. In Lipids and Essential Oils as Antimicrobial Agents; John Wiley \& Sons, Ltd.: Hoboken, NJ, USA, 2010; pp. 203-238. ISBN 9780470741788.

19. El Asbahani, A.; Miladi, K.; Badri, W.; Sala, M.; Addi, E.A.; Casabianca, H.; El Mousadik, A.; Hartmann, D.; Jilale, A.; Renaud, F.; et al. Essential oils: From extraction to encapsulation. Int. J. Pharm. 2015, 483, 220-243. [CrossRef] 
20. Mazzarrino, G.; Paparella, A.; Chaves-López, C.; Faberi, A.; Sergi, M.; Sigismondi, C.; Compagnone, D.; Serio, A. Salmonella enterica and Listeria monocytogenes inactivation dynamics after treatment with selected essential oils. Food Control 2015, 50, 794-803. [CrossRef]

21. Chang, Y.; McLandsborough, L.; McClements, D.J. Fabrication, stability and efficacy of dual-component antimicrobial nanoemulsions: Essential oil (thyme oil) and cationic surfactant (lauric arginate). Food Chem. 2015, 172, 298-304. [CrossRef]

22. Saad, N.Y.; Muller, C.D.; Lobstein, A. Major bioactivities and mechanism of action of essential oils and their components. Flavour Fragr. J. 2013, 28, 269-279. [CrossRef]

23. Koul, O.; Singh, R.; Kaur, B.; Kanda, D. Comparative study on the behavioral response and acute toxicity of some essential oil compounds and their binary mixtures to larvae of Helicoverpa armigera, Spodoptera litura and Chilo partellus. Ind. Crops Prod. 2013, 49, 428-436. [CrossRef]

24. Olmedo, R.; Nepote, V.; Grosso, N.R. Antioxidant activity of fractions from oregano essential oils obtained by molecular distillation. Food Chem. 2014, 156, 212-219. [CrossRef]

25. Ebada, S.S.; Lin, W.; Proksch, P. Bioactive sesterterpenes and triterpenes from marine sponges: Occurrence and pharmacological significance. Mar. Drugs 2010, 8, 313-346. [CrossRef] [PubMed]

26. Sobral, M.V.; Xavier, A.L.; Lima, T.C.; De Sousa, D.P. Antitumor activity of monoterpenes found in essential oils. Sci. World J. 2014, 2014, 35. [CrossRef] [PubMed]

27. Grigore, A.; Paraschiv, I.; Colceru-Mihul, S.; Bubueanu, C.; Draghici, E.; Ichim, M. Chemical composition and antioxidant activity of Thymus vulgaris L. volatile oil obtained by two different methods. Helios 2010, 15, 5436-5443.

28. Sonboli, A.; Esmaeili, M.A.; Gholipour, A.; Kanani, M.R. Composition, cytotoxicity and antioxidant activity of the essential oil of Dracocephalum surmandinum from Iran. Nat. Prod. Commun. 2010, 5, 341-344. [CrossRef]

29. Sá, R.D.C.D.S.E.; Andrade, L.N.; De Sousa, D.P. A review on anti-inflammatory activity of monoterpenes. Molecules 2013, 18, 1227-1254. [CrossRef]

30. Solomakos, N.; Govaris, A.; Koidis, P.; Botsoglou, N. The antimicrobial effect of thyme essential oil, nisin, and their combination against Listeria monocytogenes in minced beef during refrigerated storage. Food Microbiol. 2008, 25, 120-127. [CrossRef]

31. Bassolé, I.H.N.; Juliani, H.R. Essential oils in combination and their antimicrobial properties. Molecules 2012, 17, 3989-4006. [CrossRef]

32. Ambrosio, C.M.S.; de Alencar, S.M.; de Sousa, R.L.M.; Moreno, A.M.; Da Gloria, E.M. Antimicrobial activity of several essential oils on pathogenic and beneficial bacteria. Ind. Crops Prod. 2017, 97, 128-136. [CrossRef]

33. Cosentino, S.; Tuberoso, C.I.G.; Pisano, B.; Satta, M.; Mascia, V.; Arzedi, E.; Palmas, F. In-vitro antimicrobial activity and chemical composition of Sardinian Thymus essential oils. Lett. Appl. Microbiol. 1999, 29, 130-135. [CrossRef] [PubMed]

34. Bajpai, V.K.; Baek, K.H.; Kang, S.C. Control of Salmonella in foods by using essential oils: A review. Food Res. Int. 2012, 45, 722-734. [CrossRef]

35. Haas, A.N.; Wagner, T.P.; Muniz, F.W.M.G.; Fiorini, T.; Cavagni, J.; Celeste, R.K. Essential oils-containing mouthwashes for gingivitis and plaque: Meta-analyses and meta-regression. J. Dent. 2016, 55, 7-15. [CrossRef] [PubMed]

36. Dagli, N.; Dagli, R.; Mahmoud, R.; Baroudi, K. Essential oils, their therapeutic properties, and implication in dentistry: A review. J. Int. Soc. Prev. Community Dent. 2015, 5, 335. [CrossRef] [PubMed]

37. Peralta, S.L.; Valente, L.L.; Bueno, A.S.; Piva, E.; Lund, R.G. Antibacterial and mechanical properties of one experimental adhesive containing essential oil. Dent. Mater. 2011, 27, e15. [CrossRef]

38. Moalic, E.; Gestalin, A.; Quinio, D.; Gest, P.E.; Zerilli, A.; Le Flohic, A.M. The extent of oral fungal flora in 353 students and possible relationships with dental caries. Caries Res. 2001, 35, 149-155. [CrossRef]

39. Sedgley, C.M.; Samaranayake, L.P.; Chan, J.C.Y.; Wei, S.H.Y. A 4-year longitudinal study of the oral prevalence of enteric gram-negative rods and yeasts in Chinese children. Oral Microbiol. Immunol. 1997, 12, 183-188. [CrossRef]

40. Jacob, L.S.; Flaitz, C.M.; Nichols, C.M.; Hicks, M.J. Role of dentinal carious lesions in the pathogenesis of oral candidiasis in HIV infection. J. Am. Dent. Assoc. 1998, 129, 187-194. [CrossRef]

41. Shen, S.; Samaranayake, L.; Yip, H.; Dyson, J. Bacterial and yeast flora of root surface caries in elderly, ethnic Chinese. Oral Dis. 2002, 8, 207-217. [CrossRef] 
42. Nikawa, H.; Yamashiro, H.; Makihira, S.; Nishimura, M.; Egusa, H.; Furukawa, M.; Setijanto, D.; Hamada, T. In vitro cariogenic potential of Candida albicans. Mycoses 2003, 46, 471-478. [CrossRef] [PubMed]

43. Jenkinson, H.F.; Lala, H.C.; Shepherd, M.G. Coaggregation of Streptococcus sanguis and other streptococci with Candida albicans. Infect. Immun. 1990, 58, 1429-1436. [CrossRef] [PubMed]

44. Kim, D.; Sengupta, A.; Niepa, T.H.R.; Lee, B.-H.; Weljie, A.; Freitas-Blanco, V.S.; Murata, R.M.; Stebe, K.J.; Lee, D.; Koo, H. Candida albicans stimulates Streptococcus mutans microcolony development via cross-kingdom biofilm-derived metabolites. Sci. Rep. 2017, 7, 41332. [CrossRef] [PubMed]

45. Maijala, M.; Rautemaa, R.; Järvensivu, A.; Richardson, M.; Salo, T.; Tjäderhane, L. Candida albicans does not invade carious human dentine. Oral Dis. 2007, 13, 279-284. [CrossRef]

46. Sienkiewicz, M.; Łysakowska, M.; Denys, P.; Kowalczyk, E. The antimicrobial activity of thyme essential oil against multidrug resistant clinical bacterial strains. Microb. Drug Resist. 2012, 18, 137-148. [CrossRef]

47. Grzesiak, B.; Głowacka, A.; Krukowski, H.; Lisowski, A.; Lassa, H.; Sienkiewicz, M. The in vitro efficacy of essential oils and antifungal drugs against prototheca zopfii. Mycopathologia 2016, 181, 609-615. [CrossRef]

48. Sienkiewicz, M.; Glowacka, A.; Kowalczyk, E.; Wiktorowska-Owczarek, A.; Jóźwiak-Bębenista, M.; Łysakowska, M. The biological activities of cinnamon, geranium and lavender essential oils. Molecules 2014, 19, 20929-20940. [CrossRef]

49. Sienkiewicz, M.; Łysakowska, M.; Kowalczyk, E.; Szymańska, G.; Kochan, E.; Krukowska, J.; Olszewski, J.; Zielińska-Bliźniewska, $\mathrm{H}$. The ability of selected plant essential oils to enhance the action of recommended antibiotics against pathogenic wound bacteria. Burns 2017, 43, 310-317. [CrossRef]

50. Gniewosz, M.; Kraśniewska, K.; Kosakowska, O.; Pobiega, K.; Wolska, I. Chemical compounds and antimicrobial activity of petitgrain (Citrus aurantium L. var. amara) essential oil. Herba Pol. 2018, 63, 18-25. [CrossRef]

51. Budzyńska, A.; Sadowska, B.; Lipowczan, G.; Maciąg, A.; Kalemba, D.; Różalska, B. Activity of selected essential oils against Candida spp. strains. Evaluation of New aspects of their specific pharmacological properties, with special reference to lemon balm. Adv. Microbiol. 2013, 3, 317-325. [CrossRef]

52. Sienkiewicz, M.; Poznańska-Kurowska, K.; Kaszuba, A.; Kowalczyk, E. The antibacterial activity of geranium oil against Gram-negative bacteria isolated from difficult-to-heal wounds. Burns 2014, 40, 1046-1051. [CrossRef] [PubMed]

53. The European Pharmacopoeia (Ph. Eur.) 10th Edition. Available online: https://www.edqm.eu/en/europeanpharmacopoeia-ph-eur-10th-edition (accessed on 5 September 2020).

54. Botelho, M.A.; Nogueira, N.A.P.; Bastos, G.M.; Fonseca, S.G.C.; Lemos, T.L.G.; Matos, F.J.A.; Montenegro, D.; Heukelbach, J.; Rao, V.S.; Brito, G.A.C. Antimicrobial activity of the essential oil from Lippia sidoides, carvacrol and thymol against oral pathogens. Braz. J. Med. Biol. Res. 2007, 40, 349-356. [CrossRef] [PubMed]

55. Łysakowska, M.E.; Sienkiewicz, M.; Banaszek, K.; Sokołowski, J.; McPhee, D.J. The sensitivity of endodontic Enterococcus spp. strains to geranium essential oil. Molecules 2015, 20, 22881-22889. [CrossRef] [PubMed]

56. Galvão, L.C.D.C.; Furletti, V.F.; Bersan, S.M.F.; Da Cunha, M.G.; Ruiz, A.; De Carvalho, J.E.; Sartoratto, A.; Rehder, V.L.G.; Figueira, G.M.; Duarte, M.C.T.; et al. Antimicrobial activity of essential oils against Streptococcus mutans and their antiproliferative effects. Evid. Based Complement. Altern. Med. 2012, 2012. [CrossRef]

57. Radwan, I.A.; Abed, A.H.; Abeer, M.R.; Ibrahim, M.A.; Abdallah, A.S. Effect of thyme, clove and cinnamon essential oils on Candida albicans and moulds isolated from different sources. Am. J. Anim. Vet. Sci. 2014, 9, 303-314. [CrossRef]

58. Swamy, M.K.; Akhtar, M.S.; Sinniah, U.R. Antimicrobial properties of plant essential oils against human pathogens and their mode of action: An updated review. Evid. Based Complement. Altern. Med. 2016, 2016. [CrossRef]

59. Jokstad, A. Secondary caries and microleakage. Dent. Mater. 2016, 32, 11-25. [CrossRef]

60. Cummins, D. The development and validation of a new technology, based upon $1.5 \%$ arginine, an insoluble calcium compound and fluoride, for everyday use in the prevention and treatment of dental caries. J. Dent. 2013, 41, S1-S11. [CrossRef]

61. Kulshrestha, S.; Khan, S.; Hasan, S.; Khan, M.E.; Misba, L.; Khan, A.U. Calcium fluoride nanoparticles induced suppression of Streptococcus mutans biofilm: An in vitro and in vivo approach. Appl. Microbiol. Biotechnol. 2015, 100, 1901-1914. [CrossRef] 
62. Freires, I.A.; Denny, C.; Benso, B.; De Alencar, S.M.; Rosalen, P.L. Antibacterial activity of essential oils and their isolated constituents against cariogenic bacteria: A systematic review. Molecules 2015, 20, 7329-7358. [CrossRef]

63. Lapinska, B.; Klimek, L.; Sokolowski, J.; Lukomska-Szymanska, M. Dentine surface morphology after chlorhexidine application-SEM study. Polymers 2018, 10, 905. [CrossRef] [PubMed]

64. Lukomska-Szymanska, M.; Sokolowski, J.; Lapinska, B. Chlorhexidine-Mechanism of action and its application to dentistry. J. Stomatol. 2017, 70, 405-417. [CrossRef]

65. Szczepanski, S.; Lipski, A. Essential oils show specific inhibiting effects on bacterial biofilm formation. Food Control 2013, 36, 224-229. [CrossRef]

66. Zainal-Abidin, Z. Anti-bacterial activity of cinnamon oil on oral pathogens. Open Conf. Proc. J. 2014, 4, 12-16. [CrossRef]

67. Almeida, L.; De Paula, J.F.; De Almeida, R.V.D.; Williams, D.W.; Hebling, J.; Cavalcanti, Y.W. Efficacy of citronella and cinnamon essential oils on Candida albicans biofilms. Acta Odontol. Scand. 2016, 74, 393-398. [CrossRef]

68. Moon, S.E.; Kim, H.Y.; Cha, J.D. Synergistic effect between clove oil and its major compounds and antibiotics against oral bacteria. Arch. Oral Biol. 2011, 56, 907-916. [CrossRef]

69. Gupta, C.; Kumari, A.; Garg, A.P.; Catanzaro, R.; Marotta, F. Comparative study of cinnamon oil and clove oil on some oral microbiota. Acta Biomed. 2011, 82, 197-199.

70. Pramod, K.; Ansari, S.H.; Ali, J. Eugenol: A natural compound with versatile pharmacological actions. Nat. Prod. Commun. 2010, 5, 1999-2006. [CrossRef]

71. Prabuseenivasan, S.; Jayakumar, M.; Ignacimuthu, S. In vitro antibacterial activity of some plant essential oils. BMC Complement. Altern. Med. 2006, 6, 39. [CrossRef]

72. Chaudhari, L.K.D.; Jawale, B.A.; Sharma, S.; Sharma, H.; Kumar, H.S.C.M.; Kulkarni, P.A. Antimicrobial activity of commercially available essential oils against Streptococcus mutans. J. Contemp. Dent. Pract. 2012, 13, 71-74. [CrossRef]

73. Arora, R.; Rao, M.H. Comparative evaluation of the antibacterial effects of four dentine bonding systems: An in vitro study. J. Conserv. Dent. 2013, 16, 466-470. [CrossRef] [PubMed]

74. Wińska, K.; Mączka, W.; Łyczko, J.; Grabarczyk, M.; Czubaszek, A.; Szumny, A. Essential oils as antimicrobial agents-Myth or real alternative? Molecules 2019, 24, 2130. [CrossRef] [PubMed]

75. Lambert, R.J.W.; Skandamis, P.N.; Coote, P.J.; Nychas, G.J.E. A study of the minimum inhibitory concentration and mode of action of oregano essential oil, thymol and carvacrol. J. Appl. Microbiol. 2001, 91, 453-462. [CrossRef] [PubMed]

76. Nosrat, A.; Bolhari, B.; Shariffian, M.R.; Aligholi, M.; Mortazavi, M.S. The effect of Carvacrol on Enterococcus faecalis as a final irrigant Archive of SID. Int. Endod. J. 2009, 4, 96-100.

77. Fani, M.; Kohanteb, J. In Vitro antimicrobial activity of thymus vulgaris essential oil against major oral pathogens. J. Evid. Based Complement. Altern. Med. 2017, 22, 660-666. [CrossRef] [PubMed]

78. Neto, A.C.D.R.; Navarro, B.B.; Canton, L.; Maraschin, M.; Di Piero, R.M. Antifungal activity of palmarosa (Cymbopogon martinii), tea tree (Melaleuca alternifolia) and star anise (Illicium verum) essential oils against Penicillium expansum and their mechanisms of action. LWT 2019, 105, 385-392. [CrossRef]

79. Soković, M.; Glamočlija, J.; Marin, P.D.; Brkić, D.; van Griensven, L.J.L.D. Antibacterial effects of the essential oils of commonly consumed medicinal herbs using an in vitro model. Molecules 2010, 15, 7532-7546. [CrossRef]

80. Nedeljkovic, I.; Teughels, W.; De Munck, J.; Van Meerbeek, B.; Van Landuyt, K.L. Is secondary caries with composites a material-based problem? Dent. Mater. 2015, 31, e247-e277. [CrossRef]

(C) 2020 by the authors. Licensee MDPI, Basel, Switzerland. This article is an open access article distributed under the terms and conditions of the Creative Commons Attribution (CC BY) license (http://creativecommons.org/licenses/by/4.0/). 